\title{
Depression, Anxiety and Associated Factors Among Chronic Medical Patients Amid COVID-19 Pandemic in Mettu Karl Referral Hospital, Mettu, Ethiopia, 2020
}

This article was published in the following Dove Press journal:

Neuropsychiatric Disease and Treatment

\author{
Mohammedamin Hajure (iD ${ }^{1}$ \\ Mandaras Tariku ${ }^{2}$ \\ Mustefa Mohammedhussein (iD) \\ Aman Dule (iD \\ 'Department of Psychiatry, College of \\ Health Sciences, Mettu University, Mettu, \\ Ethiopia; ${ }^{2}$ Department of Psychiatry, \\ College of Health and Medical Sciences, \\ Haramaya University, Harar, Ethiopia
}

\begin{abstract}
Background: COVID-19 has had a devastating impact on the mental health condition of the world's population. Although the direct effect of COVID-19 on the mental health status of chronic medical patients is well understood, the burden of depression and anxiety on patients with chronic medical conditions is not well studied yet. Therefore, the study aimed to assess the prevalence of depression, anxiety and associated factors among chronic medical patients amid the COVID-19 pandemic in Mettu Karl Referral Hospital, Mettu, Ethiopia.
\end{abstract}

Methods: A facility-based cross-sectional study was conducted from June 1 to July 30, 2020 among chronic medical patients in Mettu Karl Referral Hospital, Ethiopia. Consecutive sampling technique was applied with a total of 423 samples. Quantitative data were employed by using structured questionnaires. Descriptive statistical procedures, bivariate and multivariate logistic regressions with odds ratios and $95 \%$ confidence interval (CI) were employed. The statistical significance was declared at $\mathrm{p}$ value $<0.05$.

Results: The findings showed that the prevalence of depression and anxiety among chronic medical patients was $55.7 \%$ and $61.8 \%$, respectively. Female gender (AOR $=1.66,95 \% \mathrm{CI}$ $(1.06,2.59))$, poor social support $(\mathrm{AOR}=1.94,95 \% \mathrm{CI}(1.10,3.42))$, widowed/divorced $(\mathrm{AOR}$ $=3.92,95 \% \mathrm{CI}(1.59,9.64))$, separated $(\mathrm{AOR}=3.66,95 \% \mathrm{CI}(1.64,8.19))$, and longer duration of illness $(\mathrm{AOR}=1.82,95 \% \mathrm{CI}(1.15,2.89))$ were significantly associated with depression, whereas earlier age at onset of illness, having more than three co-morbid diagnoses, tobacco use and poor social support were found to have significant association with anxiety among chronic medical patients amid the COVID-19 pandemic in Ethiopia.

Conclusion: The magnitude of concurrent depression and anxiety in the current study was high. Strategies for prompt identification and treatment of depression and anxiety should be developed among medically ill patients.

Keywords: anxiety, COVID-19, depression, chronic illness, Ethiopia

\section{Introduction}

From the past experience, epidemic or pandemic viral diseases such as Ebola, Swine Flu (H1N1 subtype), Middle East Respiratory Syndrome (MERS) and Severe Acute Respiratory Syndrome (SARS) were the cause of huge public health crises. These infections had overwhelmed populations and caused massive morbidity and extensively increased profound psychological distress, depression and anxiety. ${ }^{1}$ In a similar manner, novel corona virus disease (COVID-19) is known to cause serious physical illness, like heart and respiratory failure, ${ }^{2}$ it attacks multisystems frequently, ${ }^{3}$ affects mental health ${ }^{4}$
Correspondence: Mohammedamin Hajure Department of Psychiatry, College of Health Sciences, Mettu University, Mettu, Ethiopia Email sikoado340@gmail.com

Neuropsychiatric Disease and Treatment 2020:16 25II-25I8

2511 
and the psychological well-being of people ${ }^{5}$ in which people with background medical problems were at high risk. ${ }^{6}$ The pandemic is influencing mental health and causing psychological distress in the population with underlying medical conditions, especially those who have chronic medical illnesses. ${ }^{7}$

The study done in the Republic of Korea during the MERS outbreak reported $27 \%$ and $25.58 \%$ occurrence of depression and anxiety respectively which was associated with gender and a previous history of medical illness. ${ }^{8}$ In one study of SARS survivors, elevated anxiety and depression (mean score of the 21-item Depression Anxiety Stress Scales was 10.4 \pm 8.0 and $11.1 \pm 9.1$ respectively) were reported with an occurrence of $36.7 \%$ (anxiety) and 36.3\% (depression) among participants, which was significantly higher in women. ${ }^{9}$

The COVID-19 pandemic has caused moderate to extremely severe depression (16.5\%) and anxiety (25\%) among people with chronic medical illness in Spain, ${ }^{10}$ as well as $32.4 \%$ and $18.7 \%$ of moderate to severe depression in Italy and this was associated with unemployment, female gender, low educational level and medical problems. ${ }^{11}$

Supportive findings were reported from Spain in which $31.8 \%$ and $31.5 \%$ of people with chronic illness had depressive and anxiety symptoms during the COVID-19 pandemic. Accordingly, women had lower mean score for depression while higher mean than men for anxiety symptoms. ${ }^{12}$ One review study of viral epidemic impacts revealed that the pooled anxiety and depression prevalence was $45 \%$ and $38 \%$, respectively and high impacts were associated with female gender and younger age. ${ }^{13}$

Generally, existing materials pointed out that, the occurrence of psychological distress due to the pandemic is heterogeneous ${ }^{14}$ and individuals with a chronic medical illness were anticipated to have high levels of anxiety and depression. $^{12}$

Therefore, this study aimed to measure the prevalence of depression and anxiety among people with a chronic medical condition during the COVID-19 pandemic as they are one of the at risk groups. To our knowledge, this is the first study in our country context and is intended to add value in policy making and combat the impact of the pandemic on the mental health status of patients with chronic medical conditions.

\section{Materials and Methods}

\section{Participants and Setting}

A cross-sectional study was conducted among patients with chronic medical illnesses at Mettu Karl Referral Hospital from June 1 to July 30, 2020. Patients on follow-up and aged 18 and above were included and those with an acute exacerbation of the illness were excluded from the study.

The study population consisted of all patients attending follow up treatment and aged 18 and above at Mettu Karl referral hospital who were included in the sample.

\section{Sample Size and Procedures}

The minimum required sample size was calculated by single population proportion formula as follows:- $\mathrm{n}=\frac{\left(\mathrm{z}_{\alpha / 2}\right)^{2} \mathrm{p}(1-\mathrm{P})}{\mathrm{d}^{2}}$

Considering $95 \%$ confidence interval, $50 \%$ population proportion and $5 \%$ margin of error, the sample size was 384. Including a $10 \%$ non-response rate, the final sample size was 423 . The intended sample was obtained by using consecutive sampling technique.

\section{Study Variables and Instruments}

Interviewer administered questionnaires were used to collect data. The questionnaires included different subsections, including the socio-demographic, hospital and anxiety depression scales, Oslo-3 social support scale, clinical and substance related data. The prevalence of depression and anxiety was considered as the outcome variable. Clinical related factors and socio-demographic data of the participants, were considered after an extensive review of different literatures. The consistency of the questionnaires was checked by translation to local language Afan Oromo and Amharic and then retranslating back to the English version. Finally, the English version was used for actual data collection.

Depression and anxiety were assessed by the Hospital Anxiety and Depression Scale (HADS). This tool has 14 items (seven for each) which, scored in a Likert manner from $0-3$, yield a total of 21 points and distinguishes the status of anxiety and depression symptoms as normal $(0-7)$, borderline (8-10) and 11-21 (abnormal or case) with a binary cut off point of greater than $8 .{ }^{15}$ The scale has been validated in different populations in Ethiopia and internal consistency (Cronbach's alpha) was ranged from 0.78 to 0.81 for anxiety and 0.76 to 0.78 for depression subscales. $^{16,17}$

The reliability of the HADS in the current study was 0.87 .

The Oslo-3 social support scale was used to measure social support, with a sum of raw scores ranging from 3 to 14. A score was classified as poor, moderate and strong 
social support in a range of $3-8,9-12$ and 12-14 respectively. ${ }^{18}$

\section{Assessment}

Depression and anxiety. ${ }^{16}$

Social support ${ }^{18}$

Substance use - Use of at least one substance in the past 3 months.

Chronic medical illness - Includes diabetes mellitus, HIV/ AIDS, hypertension, epilepsy, cardiovascular disease, tuberculosis.

Cardiovascular disease - A group of diseases that comprise heart and/or blood vessels, excluding hypertension.

\section{Data Processing and Analysis}

The checked and cleared data were entered into Epi-data version 3.1 and exported to Statistical Package for Social Science (SPSS) version 20.0, which was used for analysis. Descriptive statistical procedures were utilized to estimate the prevalence of depression and anxiety among chronic medical patients. All independent variables with a p-value $\leq 0.20$ in bivariable logistic analysis were fitted into the final regression model to detect significantly associated predictors. Bivariate and multivariable logistic regression analysis was conducted to identify associated factors for depression and anxiety. The strength of the associated factors was presented by an odds ratio with $95 \%$ confidence interval (CI). P-values less than 0.05 were considered as statistically significant.

\section{Results and Discussion}

\section{Socio-Demographic Characteristics of the Study Participants}

411 participants were included in the study, which yields the response rate of $97.2 \%$. The mean age and age at onset of illness of the respondents were $43.3 \pm 13.3$ and $37.6 \pm$ 12.8 years respectively. More than half of them were male $233(56.7 \%)$ and about one third of the participants attended secondary education and above. About 178 $(43.3 \%)$ were self-employed and few, 27 (6.6\%), were divorced women (Table 1).

\section{Clinical, Substance and Psychosocial Characteristics of the Study Participants}

Most of the participants, $130(31.7 \%)$ had a diagnosis of HIV/AIDS, followed by diabetes mellitus 105 (25.6\%). About one fourth of the total participants had other comorbid diagnosis and $64(15.6 \%)$ of them had about one to two diagnoses. About $161(39.2 \%)$ of them engaged in regular physical activity and the majority, $331(80.5 \%)$, of them were prescribed 1-2 medication on a daily basis. Age at onset of illness of greater than 37years makes up the majority and current use of alcohol 191 (46.5\%) constitutes the majority (Table 2).

\section{Prevalence of Depression and Anxiety Among Chronic Medical Patients Amid the COVID-19 Pandemic}

As the study was conducted during the COVID-19 era, significant proportions of the patients reported symptoms of anxiety and depression. Accordingly, the prevalence of depression and anxiety among chronic medical patients were $55.7 \%$ (95\% CI 50.6, 60.3) and 61.8\% (95\% CI $57.2,66.4)$ respectively.

\section{Correlates of Depression Among Patients with Chronic Medical IIIness}

In the final regression analysis female gender, marital status (widowed/divorced, separated), poor social support, and greater duration ( $\geq 6$ years) of illness were found to be independent predictors of depression among patients with a chronic medical illness. Accordingly, the odds of developing depression among females were 1.7 times $(\mathrm{AOR}=$ $1.66,95 \% \mathrm{CI}(1.06,2.59))$ higher compared to their counterparts and 1.94 times $(\mathrm{AOR}=1.94,95 \% \mathrm{CI}(1.10,3.42)$ ) among patients with poor social support compared to those with good social support. In other ways, the odds of having depression among widowed/divorced and separated residents were 4 times $(\mathrm{AOR}=3.92,95 \% \mathrm{CI}(1.59,9.64))$ and 3.7 times more likely $(\mathrm{AOR}=3.66,95 \%$ CI $(1.64$, 8.19)), respectively. A longer duration of illness was 1.8 times more likely to develop depression among patients with chronic medical illness (AOR $=1.82,95 \%$ CI $(1.15$, 2.89)) (Table 3).

\section{Correlates of Anxiety Among Patients with Chronic Medical Illness}

Considering predictors of anxiety among patients with chronic medical illness, earlier age at onset of illness (less than 36 years), having more than three co-morbid diagnosis, past three month use of tobacco, and poor social support were found to have significant associations with anxiety symptoms in the final multivariate regression analysis. Early age at onset of illness was 1.8 times (AOR = 1.78, 95\% CI $(1.15,2.78))$ more likely associated with 
Table I Description of the Socio-Demographic Characteristics of the Patients with Chronic Medical IIIness Amid COVID-I 9 Pandemic in Mettu Karl Referral Hospital, Southwest Ethiopia ( $=4 \mathrm{I}$ )

\begin{tabular}{|c|c|c|c|}
\hline Variables & Category & Frequency & Percentage \\
\hline \multirow[t]{2}{*}{ Sex } & Male & 217 & 52.8 \\
\hline & Female & 194 & 47.2 \\
\hline \multirow[t]{5}{*}{ Age (in years) } & $18-24$ & 58 & 14.1 \\
\hline & $25-34$ & 30 & 7.3 \\
\hline & $35-44$ & 103 & 25.1 \\
\hline & $45-54$ & 108 & 26.3 \\
\hline & $>55$ & 112 & 27.3 \\
\hline \multirow{2}{*}{$\begin{array}{l}\text { Age at onset of } \\
\text { illness }\end{array}$} & $<36$ & 181 & 44.0 \\
\hline & $\geq 37$ & 230 & 56.0 \\
\hline \multirow[t]{5}{*}{ Marital status } & Single & 101 & 24.6 \\
\hline & Separated & 44 & 10.7 \\
\hline & Married & 235 & 57.2 \\
\hline & Widowed/ & 31 & 7.5 \\
\hline & divorced & & \\
\hline \multirow[t]{4}{*}{ Occupation } & Government & 99 & 24.1 \\
\hline & worker & & \\
\hline & Self-employed & 126 & 30.7 \\
\hline & Unemployed & 186 & 45.3 \\
\hline \multirow[t]{4}{*}{ Educational status } & $\begin{array}{l}\text { No formal } \\
\text { education }\end{array}$ & & \\
\hline & $\begin{array}{l}\text { Primarily } \\
(1-8)\end{array}$ & 231 & 56.2 \\
\hline & Secondary & 149 & 36.3 \\
\hline & and above & & \\
\hline \multirow{2}{*}{$\begin{array}{l}\text { Residence in the } \\
\text { past } 2 \text { weeks }\end{array}$} & Urban & $24 I$ & 58.6 \\
\hline & Rural & 170 & $4 I .1$ \\
\hline \multirow[t]{3}{*}{ Family size } & $1-2$ & 160 & 38.9 \\
\hline & 3 & 50 & 12.2 \\
\hline & 4 and above & 201 & 48.9 \\
\hline
\end{tabular}

anxiety and having more than three co-morbid diagnosis were significantly associated with anxiety compared to their counterparts $(\mathrm{AOR}=3.35,95 \%$ CI $(1.54,7.31)$ ). Past three months use of tobacco were 2 times $(\mathrm{AOR}=$ $2.27,95 \%$ CI $(1.20,4.30))$ more likely to have associated with anxiety compared to non-users. As well, odds of developing anxiety symptoms were higher among patients with poor social support compared with strong social support $(\mathrm{AOR}=5.36,95 \% \mathrm{CI}(3.04,9.46))($ Table 4$)$.

\section{Discussion}

To the best of our knowledge, this is the first finding that determined the prevalence and associated factors with
Table 2 Clinical and Psychosocial Characteristics of the Patients with Chronic Medical Illness Amid COVID-19 Pandemic in Mettu Karl Referral Hospital, Southwest Ethiopia $(\mathrm{N}=4 \mathrm{II})$

\begin{tabular}{|c|c|c|c|}
\hline Variables & Category & $\begin{array}{l}\text { Frequency } \\
\text { (N) }\end{array}$ & $\begin{array}{l}\text { Percent } \\
(\%)\end{array}$ \\
\hline $\begin{array}{l}\text { Presence of co- } \\
\text { morbidity }\end{array}$ & $\begin{array}{l}\text { Yes } \\
\text { No }\end{array}$ & $\begin{array}{l}84 \\
327\end{array}$ & $\begin{array}{l}20.4 \\
79.6\end{array}$ \\
\hline $\begin{array}{l}\text { Number of } \\
\text { medication used }\end{array}$ & $\begin{array}{l}1-2 \\
\geq 3\end{array}$ & $\begin{array}{l}356 \\
55\end{array}$ & $\begin{array}{l}86.6 \\
13.4\end{array}$ \\
\hline Physical activity & $\begin{array}{l}\text { Yes } \\
\text { No }\end{array}$ & $\begin{array}{l}161 \\
250\end{array}$ & $\begin{array}{l}39.2 \\
60.8\end{array}$ \\
\hline Social support & $\begin{array}{l}\text { Poor } \\
\text { Moderate } \\
\text { Strong }\end{array}$ & $\begin{array}{l}105 \\
167 \\
139\end{array}$ & $\begin{array}{l}25.5 \\
40.6 \\
33.8\end{array}$ \\
\hline $\begin{array}{l}\text { Number of co- } \\
\text { morbidity }\end{array}$ & $\begin{array}{l}0 \\
\mathrm{I}-2 \\
\geq 3\end{array}$ & $\begin{array}{l}327 \\
50 \\
34\end{array}$ & $\begin{array}{l}79.6 \\
12.2 \\
8.3\end{array}$ \\
\hline Tobacco use & $\begin{array}{l}\text { Yes } \\
\text { No }\end{array}$ & $\begin{array}{l}56 \\
355\end{array}$ & $\begin{array}{l}13.6 \\
86.4\end{array}$ \\
\hline Alcohol use & $\begin{array}{l}\text { Yes } \\
\text { No }\end{array}$ & $\begin{array}{l}191 \\
220\end{array}$ & $\begin{array}{l}46.5 \\
53.5\end{array}$ \\
\hline Khat use & $\begin{array}{l}\text { Yes } \\
\text { No }\end{array}$ & $\begin{array}{l}79 \\
332\end{array}$ & $\begin{array}{l}19.2 \\
80.8\end{array}$ \\
\hline Duration of illness & $\begin{array}{l}\leq 5 \\
\geq 6\end{array}$ & $\begin{array}{l}179 \\
232\end{array}$ & $\begin{array}{l}43.6 \\
56.4\end{array}$ \\
\hline Current diagnosis & $\begin{array}{l}\text { Diabetes } \\
\text { mellitus } \\
\text { HIV/AIDS } \\
\text { Epilepsy } \\
\text { Hypertension } \\
\text { Tuberculosis } \\
\text { Cardiovascular } \\
\text { disease }\end{array}$ & $\begin{array}{l}105 \\
130 \\
75 \\
44 \\
35 \\
22\end{array}$ & $\begin{array}{l}25.6 \\
\\
31.7 \\
18.2 \\
10.7 \\
8.5 \\
5.4\end{array}$ \\
\hline
\end{tabular}

depression and anxiety among chronic medical patients amid the COVID-19 pandemic in Ethiopia. Internationally, a study on a sample of Spanish adults revealed that the current physical activity adherence to WHO guidelines in the initial phase of COVID-19 confinement correlated with both a worse current perceived anxiety and mood. ${ }^{19}$ The prevalence of depression (5.73\%) and anxiety (32\%) among patients living with a chronic medical condition in Ethiopia, before the emergence of COVID-19, ${ }^{20}$ was found to be lower compared to the finding of the current study conducted amid the COVID-19 pandemic, which revealed a high prevalence of depression $(55.7 \%)$ and anxiety (61.8\%). The finding was high as 
Table 3 Bivariate and Multivariate Analysis of Correlates with Depression Among Patients with Chronic Medical Illness Amid COVID19 Pandemic in Mettu Karl Referral Hospital, Southwest Ethiopia $(\mathrm{N}=4 \mathrm{I} \mathrm{I})$

\begin{tabular}{|c|c|c|c|c|c|}
\hline \multirow[t]{2}{*}{ Variables } & \multirow{2}{*}{ Category } & \multicolumn{2}{|l|}{ Depression } & \multirow[t]{2}{*}{ COR, $95 \%(\mathrm{Cl})$} & \multirow{2}{*}{ AOR, $95 \%(\mathrm{Cl})$} \\
\hline & & Yes N (\%) & No $\mathbf{N}(\%)$ & & \\
\hline \multirow[t]{2}{*}{ Sex } & Male & $78(43.8)$ & $100(56.2)$ & $\mathrm{I}$ & 1 \\
\hline & Female & $15 \mathrm{I}(64.8)$ & $82(35.2)$ & $1.55(1.05,2.29)$ & $1.66(1.06,2.59)$ \\
\hline \multirow[t]{4}{*}{ Marital status } & Single & $55(57.9)$ & $40(42.1)$ & 1 & I \\
\hline & Separated & $16(38.1)$ & $26(6 \mid .9)$ & $2.20(1.07,4.53)$ & $3.66(1.64,8.19)^{* *}$ \\
\hline & Married & I48(59.9) & $99(40.1)$ & $1.02(0.63,1.64)$ & $1.31(0.78,2.19)$ \\
\hline & Widowed/divorced & $10(37.0)$ & $17(63.0)$ & $3.73(1.56,8.92)$ & $3.92(1.59,9.64)^{* *}$ \\
\hline \multirow[t]{3}{*}{ Social support } & Poor & $27(33.8)$ & $53(66.2)$ & $2.09(I .25,3.5 \mathrm{I})$ & $1.94(1.10,3.42)^{*}$ \\
\hline & Moderate & $100(59.2)$ & $69(40.8)$ & $1.08(0.68,1.7 \mathrm{I})$ & $0.92(0.55,1.53)$ \\
\hline & Strong & $102(63.0)$ & $60(37.0)$ & 1 & 1 \\
\hline \multirow[t]{3}{*}{ Occupation } & Government & $66(66.7)$ & $33(33.3)$ & 1 & I \\
\hline & Self-employed & $69(54.8)$ & $57(45.2)$ & $1.65(0.96,2.85)$ & $1.55(0.82,2.93)$ \\
\hline & Unemployed & $94(50.5)$ & $92(49.5)$ & $1.96(1.18,3.25)$ & $1.76(0.98,3.18)$ \\
\hline \multirow[t]{3}{*}{ Educational status } & No formal education & $21(67.7)$ & $10(32.3)$ & $0.53(0.34,1.75)$ & $0.58(0.23,1.50)$ \\
\hline & Primarily school & $116(50.2)$ & $115(49.8)$ & $1.60(1.05,2.43)$ & $1.54(0.92,2.56)$ \\
\hline & Secondary and above & $92(61.7)$ & $57(38.3)$ & 1 & 1 \\
\hline \multirow[t]{2}{*}{ Duration of illness } & $\leq 5$ & $108(60.3)$ & $71(39.7)$ & I & I \\
\hline & $\geq 6$ & $|2|(52.2)$ & $\mathrm{II} \mid(47.8)$ & $0.62(0.34, I .13)$ & I.83(I.I5, 2.89)* \\
\hline
\end{tabular}

Notes: ${ }^{*} \mathrm{p}<0.05,{ }^{* *} \mathrm{p}<0.001, \mathrm{I}=$ reference category, NB: Khat - amphetamine like stimulant substance. Bolded numbers represent variables associated in the multivariable logistic regression.

compared with the findings of a previously conducted studies during the COVID-19 pandemic in the United Kingdom ${ }^{21}$ and Iran, ${ }^{2}$ which reported that two in five had some form of depression during the COVID-19 pandemic. This could be due to a difference in study population, a socio-cultural difference and the measurement to assess the outcome variables.

The current study identified factors associated with depression and anxiety among sufferers of a chronic medical condition amid the COVID-19 pandemic. Being female, widowed/divorced, separated, poor social support and a greater duration ( $\geq$ 6years) of illness were identified as significant variables with depression during the COVID-19 pandemic. Whereas, earlier age at onset of illness (less than 36 years), having more than three comorbid diagnosis, past three month use of tobacco and poor social support were found to have significant associations with anxiety symptoms among chronic medical patients in Ethiopia amid COVID-19.

The odds of developing depression was 1.66 times higher among female patients than male patients with chronic medical illness amid the COVID-19 pandemic $(\mathrm{AOR}=1.66,95 \% \mathrm{CI}(1.06,2.59))$. The finding is supported by previous studies conducted in China ${ }^{22}$ and $\mathrm{USA}^{23}$ that found the female gender was at a higher risk for developing depression during COVID-19 pandemic.

Separated or widowed/divorced patients were 3.66 and 3.92 times more likely to develop depression as compared with single patients $(\mathrm{AOR}=3.66,95 \% \mathrm{CI}(1.64,8.19)$ ), $(\mathrm{AOR}=3.92,95 \%$ CI $(1.59,9.64))$, respectively. This is consistent with a study conducted in the USA. ${ }^{23}$ This might be due to a difference in stress coping mechanisms between being single and those who are separated, widowed or divorced.

Regarding the duration of illness, those who have more than or equal to 6 years were more likely to develop depression $(\mathrm{AOR}=1.83,95 \% \mathrm{CI}(1.15,2.89))$, which is in agreement with findings from the national institute of mental health. ${ }^{24}$ The possible reason could be the direct effect of the co-morbid medical condition, medication used to treat medical illness, illness related anxiety or stress related to longer duration, and the severity of COVID-19 outcome among those who have another chronic medical condition and longer duration of illness.

In the present study, poor social support is an influencing factor for depression among chronic medical patients 
Table 4 Bivariate and Multivariate Analysis of Correlates with Anxiety Among Patients with Chronic Medical IIIness Amid COVID-19 Pandemic in Mettu Karl Referral Hospital, Southwest Ethiopia $(\mathrm{N}=4 \mathrm{I}$ )

\begin{tabular}{|c|c|c|c|c|c|}
\hline \multirow[t]{2}{*}{ Variables } & \multirow[t]{2}{*}{ Category } & \multicolumn{2}{|l|}{ Anxiety } & \multirow[t]{2}{*}{ COR,95\%(Cl) } & \multirow[t]{2}{*}{ AOR,95\%(Cl) } \\
\hline & & Yes $\mathbf{N}(\%)$ & No $\mathbf{N}(\%)$ & & \\
\hline Age at onset of illness & $\begin{array}{l}<36 \\
\geq 37\end{array}$ & $\begin{array}{l}99(54.7) \\
155(67.4)\end{array}$ & $\begin{array}{l}82(45.3) \\
75(32.6)\end{array}$ & $\begin{array}{l}1.81(1.17,2.79) \\
1\end{array}$ & $1.78(1.15,2.78)^{*}$ \\
\hline No of co-morbidity & $\begin{array}{l}0 \\
\mathrm{I}-2 \\
\geq 3\end{array}$ & $\begin{array}{l}210(64.2) \\
31(62.0) \\
13(38.2)\end{array}$ & $\begin{array}{l}117(35.8) \\
19(38.0) \\
21(61.8)\end{array}$ & $\begin{array}{l}\text { I } \\
\text { I.I0 }(0.59,2.03) \\
2.89(1.40,6.00)\end{array}$ & $\begin{array}{l}\text { I } \\
\text { I.I } 4(0.59,2.22) \\
3.35(1.54,7.31) * *\end{array}$ \\
\hline Current tobacco use & $\begin{array}{l}\text { Yes } \\
\text { No }\end{array}$ & $\begin{array}{l}25(44.6) \\
229(64.5)\end{array}$ & $\begin{array}{l}3 \mid(55.4) \\
126(35.5)\end{array}$ & $\begin{array}{l}2.25(1.27,3.99) * \\
\text { I }\end{array}$ & $2.27(1.20,4.30)^{*}$ \\
\hline Social support & $\begin{array}{l}\text { Poor } \\
\text { Moderate } \\
\text { Strong }\end{array}$ & $\begin{array}{l}36(34.3) \\
115(68.9) \\
103(74.1)\end{array}$ & $\begin{array}{l}69(65.7) \\
52(31.1) \\
36(25.9)\end{array}$ & $\begin{array}{l}5.48(3.15,9.54) \\
1.29(0.78,2.14) \\
I\end{array}$ & $\begin{array}{l}5.36(3.04,9.46)^{* *} \\
1.09(0.65,1.84) \\
I\end{array}$ \\
\hline Gender & $\begin{array}{l}\text { Male } \\
\text { Female }\end{array}$ & $\begin{array}{l}149(68.7) \\
105(54.1)\end{array}$ & $\begin{array}{l}68(31.3) \\
89(45.9)\end{array}$ & $\begin{array}{l}\text { I } \\
1.86(1.24,2.78)\end{array}$ & I $1.39(0.88,2.22)$ \\
\hline No of medication & $\begin{array}{l}1-2 \\
\geq 3\end{array}$ & $\begin{array}{l}228(64.0) \\
26(47.3)\end{array}$ & $\begin{array}{l}128(36.0) \\
29(52.7)\end{array}$ & $1.98(1.12,3.52)$ & $\begin{array}{l}\text { I } \\
\text { I.2I }(0.41,3.55)\end{array}$ \\
\hline Presence of co-morbidity & $\begin{array}{l}\text { Yes } \\
\text { No }\end{array}$ & $\begin{array}{l}44(52.4) \\
210(64.2)\end{array}$ & $\begin{array}{l}40(47.6) \\
117(35.8)\end{array}$ & $\begin{array}{l}1.63(1.00,2.65) \\
1\end{array}$ & $\begin{array}{l}1.65(0.22,12.26) \\
1\end{array}$ \\
\hline
\end{tabular}

Notes: ${ }^{*} \mathrm{p}<0.05,{ }^{*} \mathrm{p}<0.001, \mathrm{I}=$ reference category, bolded numbers represent variables associated in the multivariable logistic regression.

in amid the COVID-19 pandemic. The study participants who have poor social support were 1.94 times to develop depression as compared with those chronic medical patients who have strong social support $(\mathrm{AOR}=1.94$, 95\% CI $(1.10,3.42))$. This finding is consistent with the reports from World Health Organization ${ }^{25}$ and China. ${ }^{26}$

According to this study, the age at onset of illness is an influencing factor for the occurrence of anxiety among chronic medical patients in amid COVID-19. Patients aged, at first onset of illness, 37 years and above were 1.78 times more likely to develop anxiety during the COVID-19pandemic (AOR $=1.78,95 \%$ CI $(1.15,2.78)$ ). The finding agreed with a previously conducted study in Spain. ${ }^{27}$ This might be due to COVID-19 changing older people's daily routines, the care and support they receive, their ability to stay socially connected, and fear of the severity of contagion.

The odds of developing anxiety were 3.35 times higher among patients with chronic medical condition who have $\geq 3$ co-morbid illnesses than patients who have no comorbid medical illness (AOR=3.35, 95\% CI $(1.54,7.31)$ ). The finding is supported by reports from the $\mathrm{CDC}^{28}$ and Australia. ${ }^{29}$ The possible reason could be the direct effect of co-morbid medical conditions, medication used to treat medical illness, and the severity of a COVID-19 outcome among those who have multiple chronic medical conditions.

Based on the findings from this study, current tobacco users were 2.27 times more likely to develop anxiety among chronically medically ill patients $(\mathrm{AOR}=2.27$, $95 \%$ CI $(1.20,4.30))$. The finding is in line with previous studies conducted in the Netherlands ${ }^{30}$ and Australia. ${ }^{31}$ This might be due to stress and anxiety leading to a rise in tobacco use and immature coping strategies during the face of a global pandemic.

In the current study, poor social support is an influencing factor for anxiety among patients with chronic medical illness. The odds of developing anxiety were 5.36 times higher among patients with chronic medical illness who have poor social support than patients with strong social support $(\mathrm{AOR}=5.36,95 \%$ CI $(3.04,9.46))$. The result is supported by a previously conducted study in China. $^{32}$

\section{Limitation of the Study}

The cross-sectional nature of the study does not allow us to determine temporality. Overlap between physical and psychological symptoms may have distorted the diagnosis 
of depression and anxiety among patients living with chronic medical conditions. Convenience sampling was used, comprising only of clinic attendees, and so might have reduced the magnitude of anxiety and depression. Despite these limitations the current study gives an insight into the psychological disturbance among chronic medical patients amid the COVID-19 pandemic in Ethiopia.

\section{Conclusion and Recommendation}

The magnitude of concurrent depression and anxiety in the current study was high. Being female, widowed/ divorced, separated, and a greater duration ( $\geq 6$ years) of illness was significantly associated with depression, whereas earlier age at onset of illness (less than 36 years), having more than three co-morbid diagnosis, and past three month use of tobacco were found to have significant association with anxiety symptoms among chronic medical patients in Ethiopia amid COVID-19. Poor social support was associated both with depression and anxiety. Strategies for prompt identification and treatment of depression and anxiety should be developed among medically ill patients. Additionally, a longitudinal study on the identified predictors of anxiety and depression should be undertaken to strengthen the findings of the current study.

\section{Data Sharing Statement}

The data sets used and analyzed during this study are available from the corresponding author on reasonable request.

\section{Ethical Approval and Consent to Participate}

The study was conducted in agreement with the principles of the Declaration of Helsinki. Ethical clearance was obtained from the Ethical Review Board, College of Health Sciences, Mettu University. Respondents were informed about the nature, purposes, profits and adverse effects of the study and invited. Written informed consent was obtained from study participants who agreed to participate. Confidentiality was kept utmost and all related queries were responded to.

\section{Acknowledgments}

Authors are thankful to Mettu University for providing ethical clearance to undertake the study. Again our special praise extends to Mettu Karl Referral Hospital clinical staffs, data collectors, and study respondents in acquiring the necessary information.

\section{Author Contributions}

All authors made a significant contribution to the work reported, whether that is in the conception, study design, execution, acquisition of data, analysis and interpretation, or in all these areas; took part in drafting, revising or critically reviewing the article; gave final approval of the version to be published; have agreed on the journal to which the article has been submitted; and agree to be accountable for all aspects of the work.

\section{Funding}

No institution funded this article; the publishing fee was paid with the authors' funds.

\section{Disclosure}

The authors declare that they have no competing interests.

\section{References}

1. Anderson CG, Latham R, El Zerbi C, et al. Impacts of social isolation among disadvantaged and vulnerable groups during public health crises authors. Cent Soc Ment Heath. 2020.

2. Salari N, Hosseinian-far A, Jalali R, Vaisi-raygani A, Rasoulpoor S Prevalence of stress, anxiety, depression among the general population during the COVID-19 pandemic: a systematic review and meta-analysis. Global Health. 2020;18(57):1-11.

3. Barker-Davies RM, O'Sullivan O, Senaratne KPP, et al. The stanford hall consensus statement for post-COVID-19 rehabilitation. $\mathrm{Br}$ J Sports Med. 2020:1-11. doi:10.1136/bjsports-2020-102596

4. Khan S, Siddique R, Li H, et al. Impact of coronavirus outbreak on psychological health. $J$ Glob Health. 2020;10(1):1-6. doi:10.7189/ jogh.10.010331

5. Chakraborty N. The COVID-19 pandemic and its impact on mental health. Prog Neurol Psychiatry. 2020;24:21-24. doi:10.1002/pnp.666

6. Shacham M, Hamama-raz Y, Kolerman R, Mijiritsky O, Ben-Ezra M, Mijiritsky E. COVID-19 factors and psychological factors associated with elevated psychological distress among dentists and dental hygienists in Israel. Int J Environ Res Public Health. 2020;17(8):2900. doi:10.3390/ijerph17082900

7. Shi L, Lu Z-A, Que J-Y, et al. Prevalence of and risk factors associated with mental health symptoms among the general population in China during the coronavirus disease 2019 pandemic. JAMA Netw Open. 2020;3(7):1-16. doi:10.1001/jamanetworkopen.2020.14053

8. Park HY, Park WB, Lee SH, Kim JL, Lee JJ, Lee H. Posttraumatic stress disorder and depression of survivors 12 months after the outbreak of Middle East respiratory syndrome in South Korea. BMC Public Health. 2020;20:1-9.

9. Lee AM, Wong JGWS, McAlonan GM, et al. Stress and psychological distress among SARS survivors 1 year after the outbreak. Can J Psychiatry. 2007;52(4):233-240. doi:10.1177/070674370705200405

10. Ozamiz-Etxebarria N, Dosil-Santamaria M, Picaza-Gorrochategui M, Idoiaga-Mondragon N. Stress, anxiety, and depression levels in the initial stage of the COVID-19 outbreak in a population sample in the northern Spain. Cad Saude Publica. 2020;36(4):1-9. doi:10.1590/ 0102-311X00054020 
11. Mazza C, Ricci E, Biondi S, et al. A Nationwide Survey of Psychological Distress among Italian People during the COVID-19 Pandemic: immediate Psychological Responses and Associated Factors. Int J Environ Res Public Health. 2020;17:3165.

12. Ozamiz-etxebarria N, Mondragon NI, Santamaría MD, De Giorgio A. Psychological symptoms during the two stages of lockdown in response to the COVID-19 outbreak: an investigation in a sample of citizens in Northern Spain. Front Psychol. 2020;11:1-9. doi:10.3389/fpsyg.2020.01491

13. Cabello NR, Echavez JF, Serrano-Ripoll MJet al. Impact of viral epidemic outbreaks on mental health of healthcare workers: a rapid systematic review. medRxiv. 2020.

14. Zuercher SJ, Kerksieck P, Adamus C, et al. Prevalence of mental health problems during virus epidemics in the general public health care workers and survivors a rapid review of the evidence. Medrxiv. 2020:1-26. doi:10.1101/2020.05.19.20103788

15. Michopoulos I, Kalemi G, Psarra ML, Gournellis R. Hospital Anxiety and Depression Scale (HADS): validation in a Greek general hospital sample. Psychiatriki. 2010;21(4):279-286.

16. Reda AA, Mitchell A. Reliability and validity of the Ethiopian version of the Hospital Anxiety and Depression Scale (HADS) in HIV infected patients. PLoS One. 2011;6(1):1-6. doi:10.1371/journal. pone. 0016049

17. Ambaw F. Original article the structure and reliability of the amharic version of the hospital anxiety and depression scale in orphan adolescents in Addis Ababa. Ethiop J Health Sci. 2011;21 (1):27-35.

18. Abiola T, Udofia O, Zakari M. Psychometric properties of the 3-item Oslo social support scale among clinical students of Bayero University Kano, Nigeria. Malays J Psychiatry. 2013;22:32-41. doi: MJP-01-11-13

19. López-Bueno R, Calatayud J, Ezzatvar Y, et al. Association between current physical activity and current perceived anxiety and mood in the initial phase of COVID-19 confinement. Front Psychiatry. 2020;11(July):1-8. doi:10.3389/fpsyt.2020.00729

20. Edmealem A, Olis CS. Factors associated with anxiety and depression among diabetes, hypertension, and heart failure patients at Dessie Referral Hospital, Northeast Ethiopia. Behav Neurol. 2020;2020:1-10. doi:10.1155/2020/3609873

21. Fancourt D, Steptoe A, Bu F. Trajectories of depression and anxiety during enforced isolation due to COVID-19: longitudinal analyses of 59,318 adults in the UK with and without diagnosed mental illness. medRxiv. 2020. doi:10.1101/2020.06.03.20120923
22. Jiang S, Li Z, Zhang G, et al. Prevalence and socio - demographic correlates of psychological health problems in Chinese adolescents during the outbreak of COVID - 19. Eur Child Adolesc Psychiatry. 2020. doi:10.1007/s00787-020-01541-4

23. Ettman CK, Abdalla SM, Cohen GH, Sampson L, Vivier PM, Galea S. Prevalence of depression symptoms in US adults before and during the COVID-19 pandemic. JAMA Netw Open. 2020;3(9): e2019686. doi:10.1001/jamanetworkopen.2020.19686

24. National Institute of Mental Health. Chronic illness and mental health: recognizing and treating depression. 2018. Available from: http://www.nimh.nih.gov/health/topics/depression. Accessed October $13,2020$.

25. World Health Organization. Mental health and psychosocial considerations during COVID-19 outbreak. World Health Organ. 2020; January: $1-6$.

26. Id TH, Zhang T, Cai W, et al. Social support and mental health among health care workers during coronavirus disease 2019 outbreak: a moderated mediation model. PLoS One. 2020:1-14. doi: 10.1371 journal.pone. 0233831

27. Picaza M, Eiguren Munitis A, Dosil Santamaria M, et al. Stress, anxiety, and depression in people aged over 60 in the COVID-19 outbreak in a sample collected in Northern Spain. Am J Geriatr Psychiatry. 2020;28(9):993-998. doi:10.1016/j.jagp.2020.05.022

28. United States. Centers for disease control and prevention. Preliminary estimates of the prevalence of selected underlying health conditions among patients with coronavirus disease 2019. 2020. Available from: https://www.cdc.gov/mmwr/volumes/69/wr/pdfs/mm6913e2-H.pdf. Accessed October 13, 2020.

29. Australian. Coronavirus (COVID-19) advice for people with chronic health conditions. 2020. Available from: https://www.health.gov.au/. Accessed October 13, 2020.

30. Bommelé J, Hopman P, Walters BH, Geboers C, Croes E, Fong GT. The double-edged relationship between COVID-19 stress and smoking: implications for smoking cessation. Tob Induc Dis. 2020;18 (July):1-5. doi:10.18332/tid/125580

31. Stanton R, To QG, Khalesi S, et al. Depression, anxiety and stress during COVID-19: associations with changes in physical activity, sleep, tobacco and alcohol use in Australian adults. Int $J$ Environ Res Public Health. 2020;17:1-13.

32. Han B, Yan B, Zhang J, et al. The influence of the social support on symptoms of anxiety and depression among patients with silicosis. Sci World J. 2014;2014.
Neuropsychiatric Disease and Treatment

\section{Publish your work in this journal}

Neuropsychiatric Disease and Treatment is an international, peerreviewed journal of clinical therapeutics and pharmacology focusing on concise rapid reporting of clinical or pre-clinical studies on a range of neuropsychiatric and neurological disorders. This journal is indexed on PubMed Central, the 'PsycINFO' database and CAS, and

\section{Dovepress}

is the official journal of The International Neuropsychiatric Association (INA). The manuscript management system is completely online and includes a very quick and fair peer-review system, which is all easy to use. Visit http://www.dovepress.com/testimonials.php to read real quotes from published authors. 